\title{
The Uses of Power: \\ Mr Justice Denning and the Pensions Appeal Tribunals

\author{
Patrick Polden*
}

\section{Introduction}

The existence of the Denning Law Journal testifies to Lord Denning's unique importance in re-shaping English law to meet the challenges of the middle decades of the twentieth century. The massive corpus of his collected judgments has been subjected to a detailed and rigorous scholarly scrutiny of a kind not accorded to any other English judge of recent times, and his contribution to constitutional and administrative law in particular, has been analysed searchingly and, in some cases, highly critically. ${ }^{1}$ In adition, he has, of course, given us his own retrospective views on many of his most significant judgments in sundry lectures and articles and in the series of volumes beginning with The Discipline of Lan (1979) and extending to The Closing Chapter (1983). ${ }^{2}$

In all this literature, one minor but interesting part of his judicial career has received little attention. From January 1946 to October 1948, Denning J, then a puisne judge in the King's Bench Division, was the judge nominated to hear appeals from the tribunals set up under the Pensions Appeal Tribunals Act $1943^{3}$ in succession to Tucker J. It was his first foray into administrative law and gave him an unusual opportunity to develop and implement his views. The statute made no provision for a further appeal so he was constrained only by the need to respect the decisions of the nominated judges in Scotland and Northern Ireland.

In The Family Story, ${ }^{4}$ Denning recounts his relish for this taste of unfettered judicial creativity, which he used to good effect; for by the time he was elevated to the Court of Appeal, in October 1948, he had created a framework of controls and guidelines which left his successor with little scope to do more than alter emphases

* Of the Department of Law, Brunel University. I wish to thank my colleagues Mr Martin Coleman and Dr K. J. M. Smith for their helpful comments.

1. P. Robson and P. Watchman (eds.), Fustice, Lord Denning and the Constitution (1981); J. L.. Jowell and J. P. W. B. McAuslan (eds.), Lord Denning: The fudge and the Lam (1984).

2. There is a full list of his writings to 1984 in Lord Denning: The Fudge and the Law, supra n.1.

3. For an outline of Denning's career, see R. F. V. Heuston, in Lord Denning: The fudge and the Lav, supra n.1, pp.1-25.

4. (1985), p.165. Denning's predecessor, Tucker, regretted that there was no further appeal: Kemp v. Minister of Pensions (1945-6) 61 T.L.R. 341, at p.343. 
and refine procedures. Only one of his decisions, Robertson v. Ministry of Pensions, ${ }^{5}$ has proved to be of sufficient general importance to find its way into the textbooks, but of the earlier decision in Starr, Nuttall and Bourne v. Ministry of Pensions ${ }^{6}$ Professor Palley has written: "Many men would think his courageous and humane decision in Starr, affecting the welfare of many thousands of ex-servicemen and their families, was a worthwhile achievement of a lifetime". 'It is the purpose of this article to examine in more detail the reported decisions under the Act and to elucidate Denning's ideas on the proper functioning of administrative tribunals and the role of the judiciary in supervising them. First, however, it is necessary to sketch in the background to the legislation.

\section{The background}

Pensions to ex-servicemen and their families for death or disability sustained during service in the armed forces were granted under the terms of successive Royal Warrants. The unprecedented scale of the casualties in the Great War, and their being no longer confined to professional fighting men, made the administration of the Warrant a matter of much greater public concern than before. Dissatisfaction with the many decisions of the Ministry of Pensions adverse to claimants was voiced in and out of Parliament and eventually the government had to respond by establishing independent appeal tribunals. ${ }^{9}$ The Lord Chancellor was made responsible for manning the tribunals, each of which comprised a legally qualified chairman, a doctor and a disabled ex-serviceman. Although they allowed more than $20 \%$ of appeals from the Minister's decisions, the tribunals themselves came under fire, but heavy pressure to introduce a further appeal to a "supreme tribunal" was successfully resisted by the Lord Chancellor's Office. $^{10}$

When war again threatened it was apparent to those charged with contingency planning that some similar pensions provision for civilian casualties would be needed. This raised the spectre of a continuing post-war charge on government revenue of wholly unpredictable but potentially enormous dimensions, and a

5. [1949] 1 K.B. 227. The importance of the decision in public law is its extension of estoppel by representation to public authorities. See S.A. de Smith, Fudicial Reviem of Adminstrative Action 3rd ed., (1973), p.4 n.4 for speculation on Denning's own estimate of its importance.

6. [1946] 1 K.B. 345.

7. Lord Denning: The Judge and the Law, supra n.1, p.365 n.78.

8. Comparatively few decisions were reported in the general series of reports, but the semi-official War Pension Appeals Reports contain more than 300 of Denning's, as well as a handful by Tucker J, almost fifty from Scotland and two from Northern Ireland.

9. War Pensions (Administrative Provisions) Act 1919. Separate appeal tribunals to determine the assessment of the pension payable were introduced by the War Pensions Act 1921 and on these a second doctor sat instead of the lawyer. In 1940 nearly 850,000 Great War Pensions were still being paid.

10. Parl. Debs. 1922 (5th series) H. of C., vol.151, cols.320-42, 1615-39; PRO LCO 2/971. See also Sir Claud Schuster's summary in PRO LCO 2/938: Memorandum for Lord Haldane, 26.1.1924, ff.42-5. About 40 cases in which the tribunals were thought to have erred were dealt with under an unpublicised "arrangement" between the Ministry of Pensions and the Treasury. 
desire to restrict the number of war pensions payable until the total number of potential claims had become clearer may have influenced the government's decision to defer the establishment of both entitlement and assessment tribunals until the war had ended. ${ }^{11}$ Meanwhile, according to the Minister of Pensions, "The finest court of appeal in the country is available in the House of Commons."12

This position, though endorsed by the cabinet as late as March $1942,{ }^{13}$ was becoming politically untenable; more than 100,000 claims had been rejected and Aneurin Bevan had complained that the Commons order paper was becoming congested by members' attempts to bring individual cases of alleged injustice before the House. ${ }^{14}$ The ploy of appointing as Minister of Pensions a popular figure, Sir Walter Womersley (described in one debate as "a sort of bluff King Hal"), ${ }^{15}$ giving him as Parliamentary Under Secretaries Labour MPs with a reputation for championing the working man (successively Miss Ellen Wilkinson and Will Paling), and setting up an advisory committee which included some of the most vocal critics, appeased the sceptics for a while but they could only repeat the threadbare excuse that too few suitable doctors were available for the tribunals. A rising tide of backbench anger, both over the restrictive entitlement to pensions and the lack of any appeal, finally forced the government's hand after a particularly stormy debate on 23rd March 1943. ${ }^{16}$ A new, more liberal Royal Warrant and appeal tribunals were promised.

The Pensions Appeal Tribunals Bill, modelled on the earlier legislation, had its second reading on 24th June. But the Commons by now were deeply suspicious: details of the new Warrant had not been released and at the Committee stage a backbench revolt obliged the government to withdraw its Bill. ${ }^{17}$ When it returned nearly three weeks later, after the terms of the Warrant had been disclosed, it contained major concessions on the burden of proof and the strength of the causal link between service and disability and also provided for an appeal from the tribunals on a point of law. ${ }^{18}$ Given the Bill's troubled history and hasty revision, it is not surprising that those involved in the creation of the tribunals failed to appreciate the significance of the changes in the Warrant and the Bill. ${ }^{19}$ Tribunal sittings began in October 1943, and more than twenty tribunals were soon in operation.

11. Parl. Debs. 1939-40 (5th series) H. of C., vol.360, col.899.

12. Ibid., col. 705 .

13. PRO LCO $2 / 2646$.

14. Parl. Debs. 1940-1 (5th series) H. of C., vol. 370, col. 280. The Ministry always refused to make public the number of claims on the grounds of national security.

15. Parl. Debs. 1941-2 (5th series) H. of C., vol.383, col.1896, per E. Walkden.

16. Parl. Debs. (5th series) H. of C., vols.367-390 shows this growing pressure.

17. Parl. Debs. 1942-3 (5th series) H. of C., vol.390, cols.1333-1428, 1818-54.

18. Ibid., vol.391, cols.716-864, 1114-1220. For the reconstruction of the Bill see PRO LCO 2/2780.

19. PRO LCO 2/3714: G. P. Coldstream to Sir A. Napier, 9 September 1947. 
In the debates government spokesmen had laid particular emphasis on the informal procedures, which would make legal representation usually unnecessary, and on the need to avoid the fate that had befallen the Workmen's Compensation Acts. ${ }^{20}$ In the first few months the government's hope that the points of law upon which appeals were to be made to the nominated judge would be few seemed to be borne out, ${ }^{21}$ but plainly, much would turn on the interpretation placed by the nominated judge on the width of the right of appeal, since the more willing he was to entertain appeals the greater would be his opportunity to control the tribunals.

\section{The right of appeal}

\section{Procedural limitations}

As well as being limited to points of law, the right of appeal was circumscribed in two ways: first by a requirement that leave must be obtained from the tribunal or the judge (section 6(2)) and second by a six weeks time limit for appeals, imposed by rule 23(2) of the Pensions Appeal Tribunals Rules 1943; by rule 31 this period could be extended by the tribunal or the President of the Tribunals. The Great War tribunals had consistently adopted a very rigid stance against allowing appeals out of time, administrative measures having had to be taken to mitigate the injustices that resulted. ${ }^{22}$ Their successors seemed disposed to follow suit and in Richardson v. Minister of Pensions ${ }^{23}$ (May, 1945) the Court of Session held that the President's decision was not reviewable by the court. Cooper LJ-C described the six weeks time limit as "very liberal", especially since "if an appellant can adduce some good reason for a relaxation of the time limit (as, for example, that the delay has been due to illness or some accidental mischance affecting himself or his advisers) the desired indulgence will doubtless be granted: and I should assume would not be opposed by the Ministry at least in cases where the delay was slight." ${ }^{24}$ In particular, the court was not prepared to grant an extension merely on the grounds that its own decision on one appeal cast doubts on the correctness of other tribunal decisions in cases with broadly similar facts. ${ }^{25}$

This was the orthodox view, with which the Lord Chancellor and the Attorney-General were in agreement: "what had occurred was a possibility inherent in any system of law, and that if litigants did not exercise their right of appeal and subsequently a litigant does exercise his right of appeal and succeeds, the litigants in cases already decided cannot and should not have the opportunity of re-opening their cases. If such a course were allowed, the practical difficulties

20. Parl. Debs. 1942-3 (5th series) H. of C., vol.390, cols.1326, 1355-6; vol.391, cols.1205-9.

21. In the notes issued for the guidance of appellants the appeals were optimistically referred to as "rare cases".

22. PRO LCO $2 / 974,978$.

23. [1945] S.C. 363 .

24. Ibid., at p.368.

25. The Minister of Pensions had expressed a more liberal view: Parl. Debs. 1944-5 (5th series) H. of C., vol.360, cols.2239-40. 
would be insuperable."26 But Denning's decision in Starr, Nuttall and Bourne v. Minister of Pensions ${ }^{27}$ meant that as many as 27,000 tribunal decisions were probably vitiated by procedural defects. Because of the importance attached to maintaining the principle of finality in litigation and also because it was felt to be unfair to allow those claimants to appeal out of time and probably succeed on a technicality while later claimants with comparable case histories would fail on the merits of their applications, the government declined to take any action. This decision gave rise to a storm of protest in the press and in Parliament. ${ }^{28}$ The Minister's Central Advisory Committee was strongly critical and servicemen's organisations were predictably up in arms: the British Legion representative on the CAC "could not believe that the Government or the country would wish to stand on a legal position which deterred ex-servicemen from receiving pensions because their appeals happened to have been heard before certain legal pronouncements on the interpretation of the Royal Warrant had been made.,29

Neither did the Legion confine itself to political activity, for it prepared a "mass attack" by placing seventy-three representative applications for leave to appeal out of time in Denning's list. ${ }^{30}$ By unexpectedly setting these applications down for July 11th, Denning denied the government any breathing space and seems also to have made it clear that he could not be relied upon to follow Richardson. ${ }^{31}$ So to head off the "disaster" that an adverse decision threatened, the government had to come to terms with the British Legion, the applications being adjourned while a compromise was negotiated. ${ }^{32}$ The terms of the bargain were that all of these cases would be reviewed by the Ministry and claimants who were again rejected might take their case to a "Special Review Tribunal", constituted like an appeal tribunal, but with members of the highest calibre that could be procured. Although both sides might bring fresh evidence as it would be a hearing de novo, there would be no appeal from the SRT's decision. ${ }^{33}$ Here, then, the mere threat of a Denning judgment sufficed to wring a significant concession from the government. As Denning remarked in a later case, "this reserve power has often proved a decisive force in obtaining for servicemen their rights." ${ }^{34}$

Nevertheless, Denning knew the goverment's manoeuvre was designed to prevent him from delivering a highly inconvenient ruling and when he held, in Brain and Wilkes v. Minister of Pensions, ${ }^{35}$ that a tribunal erred in law when it decided against the claimant only by a majority, and thereby re-created the

26. PRO LCO 2/3711: note of meeting, May 1946.

27. [1946] 1 K.B. 345.

28. See especially Parl. Debs. 1945-6 (5th series) H. of C., vol.422, cols.1633-44.

29. PRO LCO 2/3711: W. Paling to Lord Chancellor, 16 July 1946.

30. PRO LCO 2/3711: Daily Mirror, 12 June 1946.

31. [1945] S.C. 363.

32. Supra, n.29.

33. This was announced in the Commons on 25 July: Parl. Debs. 1945-6 (5th series) H. of C., vol.426, col.2023. It was estimated that about 5,000 cases might go before the SRTs.

34. James v. Minister of Pensions [1947] 1 K.B. 867, at p.871.

35. $[1947] 1$ K.B. 625. 
situation brought about by Moxon and Starr (albeit on a much smaller scale - some eighty cases), the matter was taken to the Social Services Committee of the Cabinet, which accepted the Lord Chancellor's view that no concession to popular opinion should be made. The Attorney-General duly repeated the orthodox view of the law, yet a few months later he was forced to admit that this view was mistaken. Mrs James's husband had died of Hodgkin's Disease and in September, 1946 a tribunal had pronounced it not attributable to his war service. In November, a differently constituted tribunal held, in Donovan v. Ministry of Pensions, ${ }^{37}$ that a Hodgkin's Disease case mas attributable to war service. Mrs James was refused leave to appeal out of time and applied to the judge. ${ }^{38}$ For the Ministry, the Attorney-General and Harold Parker QC argued that the Scottish cases of Richardson and White ${ }^{39}$ should be followed, that RSC order $55 \mathrm{r} 2(1)^{40}$ governing applications for leave to appeal out of time in the King's Bench, was prohibitive and precluded this application, and that the question at issue in the case was one of fact not law.

Denning rejected each of the arguments, holding the RSC on this question to be directory, not prohibitive; it was not ousted by the Pensions Appeal Tribunals Act and the rules made under that Act did not bind the judge, ${ }^{41}$ so that he had the power to grant the application in an appropriate case. Since the Court of Session's expectation that the President would grant leave whenever it was just to do so had been falsified by experience, especially by the refusals which had obliged the government to establish the SRT's, then this was such a case. ${ }^{42}$ This was disingenuous, for Cooper $\mathrm{LJ}-\mathrm{C}$ had made it abundantly clear that he did not consider injustice would be done simply because an interpretation of the law more favourable to the claimant was given after his own time for appealing had lapsed. ${ }^{43}$ For Denning, however, "the circumstances of pension appeals differ ... from ordinary litigation. The serviceman usually appears in person, or is helped by a British Legion representative. The Minister appears by one of his officers who is not a lawyer ... The circumstances are altogether different from ordinary litigation where it is the duty of the party, and not the court, to raise any point of law on which he relies." 44 Moreover, "it is inevitable that in a field where the law has had to be declared and developed so rapidly, there should be occasional

36. PRO LCO 2/3714: memorandum to Social Services Committee, June 1947 and minutes of meeting SS[47] 4th meeting, 25 June.

37. 1 W.P.A.R. 609.

38. [1947] 1 K.B. 867. For the decision to employ the Attorney-General in this case see PRO L.CO 2/3714: R.Rieu to Lord Chancellor, 3 July 1947.

39. [1945] S.C. $363 ; 2$ W.P.A.R. 483.

40. "An appeal to the nominated judge for leave to appeal shall not be made unless an application has been made to the tribunal and has been refused."

41. [1947] 1 K.B. 867, at pp.869-70.

42. Ibid., at p.872.

43. [1945] S.C. 363 , at p.368.

44. Ibid., at p.873. 
errors." Accordingly, he proclaimed that "the doctrine of stare decisis does not apply in its full rigour to this branch of the law." 45

The second point, that in the absence of a hierarchy of appeals an erroneous judgment can only be cured by legislation if it has to be followed to the letter, is the stronger. The other seems plausible but becomes unconvincing when it is recalled that the "point of law" in question is really the one about the sufficiency of evidence which claimants regularly did take, and that the British Legion advisers were in most cases at least as expert and alive to the possibility of an error of law of this kind as the average lawyer in a county court or magistrates' court.

After James, the President of the PATs told the Lord Chancellor's Office that he would automatically grant leave out of time where the request was based on the impact of a later judgment. ${ }^{46}$ However, Denning had still not finished widening his net, and now had the "unappealable" SRT's in his sights. Mrs Gillibrand's claim had been rejected by a tribunal back in September, 1944, and was again turned down by the Ministry on review, but this widow refused to take it to an SRT; instead, following 7 ames, ${ }^{47}$ she sought leave to appeal out of time against the original decision and found Denning predictably sympathetic. ${ }^{48} \mathrm{He}$ agreed that her case should be remitted to a PAT for "from any decision of that Tribunal Mrs Gillibrand will have a right of recourse to this Court. She shall not be forced to go before a tribunal from which there is no appeal. I am glad to have the assurances of the Ministry that there will be no delay. She has waited for justice long enough." 49 The tone of this pronouncement, familiar to connoisseurs of the later Denning style, is somewhat at odds with the circumstances of the case, but it is clear that the exclusion of appeals from the SRT's rankled with him. ${ }^{50}$

He soon received an unexpected opportunity to bring even the SRTs under his control. The Legion had kept its part of the bargain, but a Mr Revely, advised by the R.A.F. Association, disregarded the understanding and, having been turned down by the Ministry (twice), by a PAT (in June, 1944) and by an SRT, applied out of time for leave to appeal against the original PAT decision. ${ }^{51}$ Using his own decisions in James and Gillibrand, ${ }^{52}$ Denning explained that a "pre-Moxon"53

\section{Ibid., at p.872.}

46. PRO LCO 2/3714: G. P. Coldstream to Sir A. Napier, 9 September 1947.

47. [1947] 1 K.B. 867.

48. [1947] W.N. 320; 1 W.P.A.R. 1039.

49. 1 W.P.A.R. 1039 , at p. 1054 .

50. It is evident from the tributes which Denning and counsel for the British Legion paid to the SRTs that it was not the actual quality of their decisions which concerned him: Revely v. Minister of Pensions 3 W.P.A.R. 1573, at pp.1581, 1583.

51. 3 W.P.A.R. 1573. The Revely case is complicated. His original appeal was allowed as to aggravation only and he did not appeal, but when his pension was stopped on a finding that the aggravation had passed away, he appealed against that decision. He was able to go to a SRT on the original decision, but could not now appeal against it to the judge (Woodrow v. Minisler of Pensions 1 W.P.A.R. 659).

52. [1947] 1 K.B. $867 ; 1$ W.P.A.R. 1039.

53. [1945] 1 K.B. 490. 
claimant now had two choices and that "continuance of this dual system is very undesirable" ${ }^{54}$ Of the three reasons he gave the important one was plainly that the SRTs might decide points of law incorrectly and uncorrectably. He therefore seized the opportunity to work out with counsel for the various parties a rather complicated procedure whereby he would effectively (though not in form) create an appeal against the decision of an SRT. ${ }^{55}$

George Coldstream summarised the effects as follows: "We have now arrived at this situation: there is a statutory right of appeal to the nominated Judge of the High Court from a decision of the statutory tribunals and it seems that Denning J will allow it to be exercised no matter what the date of the decision may have been and notwithstanding that the claimant has availed himself of the machinery of the SRTs. The very existence of the SRTs is based on the supposition that in cases rejected by the statutory tribunals before 31.7 .1946 , it is impossible for the claimant to get to the High Court. On this hypothesis, one of the main reasons for setting up the SRT procedures, disappeared. As a matter of practical effect, the new situation simply means that the claimant has a double review by the Minister of Pensions and a double appeal to a PAT." 56

\section{Law and facts}

As for the restriction of the right of appeal to points of law, Lord Denning has taken a prominent part in "the incessant conversion of questions of fact into questions of law" $" 57$ which has become such a feature of judicial practice. He playfully alluded to this technique in a lecture in $1977^{58}$ as one of the means used in policing administrative and quasi-judicial decision makers, but the boundary between the two is in any case notoriously difficult to draw with precision. ${ }^{59}$ Some questions clearly fell to be regarded as points of law; such were the definitions of "war risk injury" and "war service injury" in the schemes for compensating civilians, where there was a useful body of case law from workmen's compensation to draw upon. ${ }^{60}$ But the floodgate which Denning flung wide, and through which the British Legion channelled a torrent of appeals, was the requirement that the tribunal should limit its deliberations to, and base its decision solely upon, evidence which was logically probative.

54. 3 W.P.A.R. 1573, at p.1581.

55. Ibid., at pp.1582-84. The first such "appeal" (Ansell v. Minister of Pensions) is reported at [1948] 2 All E.R. 789.

56. PRO LCO 2/3728: Coldstream to Attorney-General, 12 August 1948. The President of the SRTs (Sir Henry Braund) declared that these decisions made them redundant, but after discussions, they were continued and Denning's circuitous "appeal" procedure was simplified: PRO LCO 2/3712, 3715, 3716; Swan v. Minister of Pensions 4 W.P.A.R. 387.

57. A.W.B. Simpson in Lord Denning: The fudge and the Lam, supra n.1, at p.450. For a general account see S.A. de Smith, Fudicial Revien of Administrative Action 3rd ed. (1973), pp.111-20.

58. See fustice, Lord Denning and the Constitution, supra n.1, at p.163.

59. A point made by Denning when criticising a tribunal for not giving assistance to a claimant in formulating her application for leave to appeal: Lee v. Minister of Pensions (No. 2) 3 W.P.A.R. 1901. 60. Examples are Ex p. Haines [1945] K.B. 183; Re Saffell [1946] 1 K.B. 259. 
This was the rule laid down by Tucker $\mathrm{J}$ in Moxon v. Minister of Pensions ${ }^{61}$ and confirmed in Starr, Nuttall and Bourne v. Minister of Pensions ${ }^{62}$ and once the Ministry amended its original practice, it was seldom that there was no medical evidence at all against the claim. It was vainly argued in Scottish cases that medical questions were to be regarded purely as questions of fact and not susceptible to appeal, ${ }^{63}$ and Denning soon gave notice that he was very willing to subject the medical evidence to detailed examination. The implications were lost neither on the government nor on the servicemen's organisations which assisted claimants. Coldstream observed that "in his judgment in Starr and Nuttall ... Denning J laid down as the test that the claim must be negatived by evidence ... It seems, however, at any rate in the learned Judge's view, to open up as a matter of law ... the question whether there was any evidence at all. Rowing and Forster ${ }^{64}$ are illustrations of this development. On this basis, every case might be appealable to the High Court, and the limitation of appeals to points of law would cease to have any meaning." He predicted that the "microscopic attention paid to the precise words used by the doctor ... will inevitably mean slowing up of the machine" and that there would be a "flood of appeals to the High Court". ${ }^{65}$ Both predictions were fulfilled to some extent.

Some chairmen of tribunals, and especially the President (A. B. Ashby), confronted with numerous notices of appeal couched in such general terms as "there was not sufficient evidence on which the tribunal could have found against the claimant", sought to hinder appellants by requiring, in effect, "further and better particulars" under rule 25 in order to prepare the statement of case for the judge $^{66}$ but Denning took a dim view of such practices, insisting that the overriding terms of rule 11 should be given effect. ${ }^{67}$

With such encouragement the appeal in very general terms became commonplace, ${ }^{68}$ although in cases where the Ministry had conceded, or the tribunal found, "aggravation" but not "attributability", it was varied to a claim that the evidence supporting one necessarily proved the other as well. ${ }^{69}$ What kept the number of appeals down was the practice of the British Legion in only promoting those which seemed to have a reasonable chance of success, rather than the formal restriction to questions of law.

61. [1945] 1 K.B. 490.

62. [1946] 1 K.B. 345.

63. Bromn v. Minister of Pensions [1946] S.C. 471; T. Bronn v. Minister of Pensions 2 W.P.A.R. 577; Paul v. Minister of Pensions 2 W.P.A.R. 633.

64. [1946] 1 All E.R. 664; 1 W.P.A.R. 145.

65. PRO LCO 2/3711: memorandum of 1 May 1946.

66. Port v. Minister of Pensions 3 W.P.A.R. 1491.

67. Lee v. Minister of Pensions (No. 2) 3 W.P.A.R. 1901. "It shall be the duty of the Tribunal to assist any Appellant who appears to them to be unable to make the best of his case" (r.11(3)).

68. Stockmell v. Minister of Pensions 1 W.P.A.R. 189.

69. E.g., Botl, Baker and McDermolt v. Minister of Pensions 3 W.P.A.R. 2167. 
Denning's determination to keep the route to the High Court open to all claimants led him to demolish all obstacles, whether embodied formally in rules or pleaded as administrative inconvenience. ${ }^{70} \mathrm{He}$ was more than willing to pay the price of a greatly increased workload, and showed none of the concern at the proliferation of appeals that he later displayed to the detriment of other claimants to state provision. ${ }^{71}$ Only one group of claimants failed to bring themselves within his jurisdiction. In Gates v. Ministry of Pensions, ${ }^{72}$ he rejected a widow's claim that it extended to appeals from tribunal decisions under the Great War legislation. Denning agreed that the body of the 1943 Act did not expressly confine it to the later war, but the long title did and recent (unspecified) authorities showed that he might use that as an aid to interpretation.

Denning's successor, Ormerod J, was even able to extend the scope of the appeal a little further. In Stephens v. Ministry of Pensions, ${ }^{73}$ against unusually strong opposition from counsel for the Ministry, he held that in an exceptional case he might re-hear and grant an application for leave to appeal out of time which he had previously refused. In doing so he was acting on a suggestion of Morton $\mathrm{LJ}$ in Exp. Aronsohn ${ }^{74}$ that this might be done where crucial new evidence had come to light. The steady flow of appeals which these decisions encouraged enabled Denning to impose on the tribunals his conception of their practice and procedure.

\section{Settling the practice of tribunals}

\section{The dethronement of the medical member}

In all his pension appeals, it is doubtful whether Denning gave a more important judgment than he did on his very first day in Starr, Nuttall and Bourne v. Ministry of Pensions. ${ }^{75}$ These were test cases arranged by the Ministry of Pensions in the hope that the new judge could be persuaded to adopt a less inconvenient approach than his predecessor, whose decision in Moxon v. Minister of Pensions ${ }^{76}$ had dismayed and disconcerted those responsible for the operation of the tribunals.

Despite the significant changes made by the Royal Warrant and the revised Bill, the tribunals, taking their lead from their President, conducted their proceedings in much the same way as under the earlier legislation and warrants. The informality stressed by ministers in Parliament was given recognition in their own rules, which expressly empowered them to take notice of facts not admissible in a

70. In addition to those mentioned, see also Bell v. Minister of Pensions 1 W.P.A.R. 965, dealing with difficulties where the claimant died before the hearing.

71. R. v. Preston Supplementary Benefit Appeals Tribunal, Ex. p. Moore [1975] 1 W.L.R. 624. This was, however, an application for certiorari.

72. 3 W.P.A.R. 2055.

73. 4 W.P.A.R. 985.

74. [1946] 2 All E.R. 544. This was the only attempt to challenge one of Denning's decisions in the Court of Appeal. The court held that it had no power to review his refusal to grant leave to appeal out of time.

75. [1946] 1 K.B. 345.

76. [1945] K.B. 490. PRO L.CO 2/3711: Coldstream's memorandum, 1 May 1946. 
court of law. ${ }^{77}$ They believed themselves able "to take judicial notice of expert medical opinion", ${ }^{78}$ whether it was (1) submitted by an independent medical specialist, to whom they were authorised to refer "difficult medical questions"; 79 (2) furnished as a signed statement by a medical practitioner and properly put in by the claimant or the Minister; (3) recited in the Minister's statement of reasons for rejecting the claim; or (4) given by the medically qualified member of the tribunal himself, either at the hearing or during its subsequent deliberations. Neither of the last two sources came within Tucker J's definition of the evidence required by $s .4$ of the Act:

"It is, I think, of the essence of "evidence", according to English ideas, when used with reference to judicial or quasi-judicial ideas, that it should consist of oral statements or documents in writing which are made in the presence or communicated to both parties before the tribunal reaches its decision ... Information communicated by the medical member to his colleagues during their deliberations does not fulfil these requirements and cannot, in my opinion, be relied upon as evidence ..."

The proper role of the medical member was crucial to the way in which the tribunals operated and in Taylor $\mathrm{v}$. Minister of Pensions ${ }^{81}$ the Ministry pressed the Court of Session to pronounce on this wider issue. ${ }^{82}$ Cooper LJ-C, with whom Lords Stevenson and Patrick concurred, agreed that it would be illegitimate for the medical member to introduce new medical "facts" without an adjournment or a reference but held that it was in order for him to advise and instruct his colleagues on what the accepted view was on any matter of medicine. Their approach to the statute was more purposive than Tucker's: "it is legitimate to infer, with the experience of the Workmen's Compensation Act in mind, that in providing for a medical member, Parliament desired, as far as possible to prevent cases of this type from developing into costly contests between arrays of expert witnesses." 83 The medical member must be more than an "animated lexicon" and need not "keep his professional knowledge and experience locked up in his breast." 84 This was much more satisfactory to the Ministry, and they contended that Denning should prefer Taylor to Moxon. ${ }^{85}$

77. Pensions Appeal Tribunals (England and Wales) Rules 1943 (No.1757/L_39), especially r.12/5; Parl. Debs. 1942-3 (5th series) H. of C., vol.390, col.1209 (Attorney-General).

78. PRO LCO 2/371:1: memorandum of 1 May 1946.

79. r. 15 .

80. Moxon v. Minister of Pensions [1945] 1 K.B. 490, at p.501.

81. [1946] S.C. 99.

82. The Court of Session's earlier decision in Brazier v. Minister of Pensions [1945] S.C. 359 was made shortly after, and in ignorance of, Moxon and took a less strict view.

83. [1946] S.C. 99, at p.108.

84. Ibid.

85. [1946] S.C. 99; [1945] l K.B. 490. 
Denning, however, firmly supported Tucker's judgment. Even if the medical member wanted to put his expert opinion forward as "evidence", he might not do so since the rules precluded him from being cross-examined, which was an essential feature of oral evidence. ${ }^{86}$ Denning pronounced that "the function of the medical member, like that of the other members, is judicial. It is not to supply evidence, but to adjudicate on the evidence" $;{ }^{87}$ and that sums up the English judges' view of the tribunals, that they should base themselves on the judicial model, weighing the evidence provided by the parties without supplementing it from their own expertise.

Just how strange and unpopular this conception was with the tribunals only becomes apparent from the response of their President and chairmen to Denning's judgment. The chairmen memorialised the government, demanding legislation either to permit the medical member to "give evidence" or, failing that, to convert both him and the service member into assessors, ${ }^{88}$ while the tone of Ashby's memoranda grew positively hysterical. It is clear that both he and the chairmen completely failed to grasp the essential changes that had been made in the terms under which they operated and had no conception that their proceedings could be seen as unfair to the claimant. His confident assertion that "Tribunals ... had always worked in that way quite smoothly, efficiently and justly ever since they were first started" was too much for Coldstream, who retorted that "it seems to me that it is impossible for the Tribunals to go on as they have been doing for the last 25 years - it was certainly not Schuster's intention that they should act now as they acted between 1920 and 1943."89

Despite their predictions of chaos, the tribunals found that they could accommodate themselves to the more judicial manner of proceeding which was now required of them. There were, of course, longer delays, more adjournments and references, ${ }^{90}$ while the Ministry of Pensions warned that their representatives "would have to be instructed to adopt a more pugnacious attitude than in the past"; ${ }^{91}$ in short, proceedings would come to resemble more closely those in a court of law. "The Lord Chancellor recognised that these results could not be avoided, but both he and the Attorney-General did not consider them to be unduly serious and they agreed moreover that the judgments of Denning J were probably correct ...".92

The "dethronement of the medical member" 93 was underlined in further judgments which denied that he might give advice to the tribunal based on his

86. [1946] 1 K.B. 345 , at p.353.

87. Ibid., at p.107.

88. PRO LCO 2/3711: A. B. Ashby, “Memorandum No. 2", 11 June 1946.

89. Ibid.; PRO L.CO 2/3711: Coldstream to Ashby, 18 June 1946.

90. Predicted in Coldstream's memorandum, supra n.78. In Parliament, court rulings were given as the reason for delays: Parl. Debs. 1946-47 (5th series) H. of C., vol.430, cols.1398-99.

91. LCO 2/3711: minute of meeting, May 1946.

92. Ibid.

93. Coldstream's phrase, supra n.78. 
observation of the claimant at the hearing or utilise medical opinion which had not been put before the tribunal, and in which even the inference that he might have gone outside his judicial role was sufficient to make the decision bad. ${ }^{94}$

The tribunal, then, was to model its deliberations on those of a court, assuming a judicial stance rather than an inquisitorial one and only seeking to interpret the 'evidence' before it. It was not limited to evidence understood by the courts, but it is not surprising, in view of the English judges' insistence on imposing the judicial model, that the tribunals sometimes erred in excluding material which satisfied the "logically probative" test. ${ }^{95}$ Denning, indeed, was anxious that they should have before them as much material, particularly of a medical nature, as necessary, in order to fill the gap left by eliminating the evidence-providing function of the medical member. To this end he actively encouraged them to resort to independent medical specialists whenever it might be useful to them or advantageous to the claimant, ${ }^{96}$ even holding that if the claimant produced a specialist's report more favourable to his claim than that of the IMS, the latter should be sent a copy and given an opportunity to reconsider his own opinion. ${ }^{97}$ Likewise, both Denning and the Court of Session insisted that the Ministry's statement, the basic record of the claimant's military service and medical history, must be full, detailed and not selective. ${ }^{98}$ Moreover, although the rules governing evidence might be less strict, the procedural safeguards for the claimant must be maintained in their full rigour: he must have an opportunity to see or hear and deal with all the evidence and to put in evidence contradicting it, ${ }^{99}$ although his failure to provide evidence on relevant matters might legitimately form the basis for unfavourable inferences. ${ }^{1}$ In order for him to be able to deal with medical evidence, it must, therefore, be couched in a form intelligible to a layman and not made too cryptic or technical. ${ }^{2}$

94. Birt v. Minister of Pensions 1 W.P.A.R. 151; Forster y. Minister of Pensions 1 W.P.A.R. 145; Hurst v. Minister of Pensions 1 W.P.A.R. 525; Heymard v. Minister of Pensions 1 W.P.A.R. 557.

95. XY v. Minister of Pensions [1947] 1 All E.R. 38 (proceedings of military court of enquiry); Baxter v. Minister of Pensions 1 W.P.A.R. 1203 (claimant's medical certificates); Donowan v. Minister of Pensions 1 W.P.A.R. 609 (medical textbooks).

96. This practice was clearly in evidence by May, 1947: see PRO LCO 2/3709: Belfray (RCJ) to Sir A. Napier 13 May 1947.

97. Harris v. Minister of Pensions 4 W.P.A.R. 73. The IMS should see all the medical evidence from both sides (Fitzhugh v. Minister of Pensions 4 W.P.A.R. 101) and the terms of the request to him should also be made available to the parties (Houlican v. Minister of Pensions 3 W.P.A.R. 1355).

98. Chairmen complained of the Ministry's selectivity and editing: PRO LCO 2/3707. The Court of Session criticised this tendency in Findlay v. Minister of Pensions [1947] S.C. 589.

99. Birl v. Minister of Pensions 1 W.P.A.R. 141. In Fox v. Minister of Pensions 1 W.P.A.R. 459 a sick claimant who had dictated her evidence at home was held entitled to have an opportunity to see and check the version put before the tribunal.

1. Childs v. Minister of Pensions 1 W.P.A.R. 679; Hunt v. Minister of Pensions 1 W.P.A.R. 1093.

2. Thompson v. Minister of Pensions 1 W.P.A.R. 479; Salter v. Minister of Pensions 1 W.P.A.R. 1195. As the Franks Commission recognised, there were limits to this: Cmnd 218 of 1957, para. 222. 


\section{The burden of proof}

Upon this material the tribunals must form their opinion, but here again it was insisted that they must work, as the courts did, within a framework of burdens and presumptions. The Warrant explicitly stated that "In no case shall there be an onus on any claimant under this Our Warrant to prove the fulfilment of the conditions [for entitlement to a pension] and the benefit of any reasonable doubt shall be given to the claimant" (article 4(2)). Moreover, by article 4(3) "where an injury or disease which has led to a member's discharge or death during war service was not noted in a medical report made on that member on the commencement of his war service, a certificate [of entitlement] shall be given unless the evidence shows that the conditions ... are not fulfilled."

Although, as Edmund Davies J later put it, "the task of interpreting article 4(2) has been bedevilled by the presence of article $4(3)$ ", 3 judges had no doubt that article 4 wrought a fundamental change by shifting the onus onto the Ministry to disprove the claim. However, perhaps because the Warrant did not expressly reverse the onus, at least some tribunal chairmen, and the Ministry of Pensions, did not fully appreciate its significance. They were given a ride awakening in the first reported case, Irving v. Ministry of Pensions, ${ }^{4}$ in which Cooper LJ-C, speaking obiter and without hearing argument, not only insisted that in every disputed fact the onus must be on one party or the other, but also remarked that the phrase, 'any reasonable doubt' seemed to place the tribunal in the position of a jury in a criminal trial. The point was fully argued and his view approved in Mitchell, ${ }^{5}$ while in England Tucker $\mathrm{J}$ insisted on the importance of the change in onus and approved the Scottish decisions, which interpreted "doubt" in article $4(2)$ as meaning "a reasonable doubt, and not a strained or fanciful acceptance of remote possibilities." Moxon was cited in Starr, ${ }^{7}$ where Denning considered the question of onus in some detail. He was particularly well qualified to do so at that time, having recently published an article entitled, "Presumptions and Burdens", which argued for a new classification of presumptions as "provisional", "compelling" and "conclusive", and of burdens into "legal", "provisional" and "ultimate" as a way out of the confusion into which he felt English judges had fallen.

In Starr, Denning held that the Minister's function was "quasi-judicial. He may be able to come to a determinate conclusion without reasonable doubt, but if the evidence leaves him in reasonable doubt, then the claimant must be given the benefit of the doubt. That means that he must not decide against the claimant on a

3. Fudd v. Minisler of Pensions and National Insurance [1965] 3 All E.R. 642, at p.648.

4. [1945] S.C. 2]

5. [1946] S.C. 131 .

6. Moxun v. Minister of Pensions [1945] 1 K.B. 490, quoting Cooper LJ-C in Irving v. Minister of Pensions [1945] S.C. 21, at p.29.

7. [1946] 1 K.B. 345.

8. (1945) 61 L.Q.R. 379. 
mere balance of probabilities ... There must be a real preponderance of probability against him such as to exclude reasonable doubt." ${ }^{9} \mathrm{He}$ also considered the meaning of article $4(3)$, which raised a "compelling presumption ... which takes the place of evidence." The distinction between claims made with the benefit of 4(3) and others was that "in order to defeat a claimant, in cases under article $4(2)$, the evidence against him must overthrow any evidence in his favour, whereas, in cases under article 4(3), it must also overthrow the presumption in his favour." 10 Even outside article 4(3) a "provisional presumption" might arise in the claimant's favour. In Roming v. Minister of Pensions ${ }^{11}$ Denning said that "if a man is accepted for service in a certain medical category there is a presumption that at the time of his acceptance he was fit for the kind of service demanded of a man in that category; and in the event of his discharge subsequently on medical grounds due to deterioration in his health, there is a presumption that the deterioration was due to his service." This was wrongly interpreted in some quarters as endorsing the slogan "fit for service, fit for pension". ${ }^{2}$

It was generally assumed, on the basis of those decisions, that the "real preponderance of probability" test was the same as in criminal cases, but subsequently, in Miller v. Minister of Pensions, ${ }^{13}$ Denning appeared to resile from that position. After expounding "with classical clarity"14 the criminal standard demanded in article 4(3) cases, he held that other cases "must be decided in favour of the man unless the evidence against him reaches the same degree of cogency as is required to discharge the burden in a civil case." 5 This ignored the decision in Irving, ${ }^{16}$ which was directly in point, and reduced the "real preponderance of probabilities such as to exclude reasonable doubt" to a much lower level. Miller was followed by Ormerod $\mathrm{J}^{17}$ and relied upon by the Ministry, but ironically (in view of Denning's special academic interest in this area), became his only pensions decision to be expressly departed from by a nominated judge. Black LJ, in a Northern Ireland case, ${ }^{18}$ was able to distinguish Miller, but Edmund Davies $\mathrm{J}$, in a full and careful judgment in $\mathcal{F} u d d \mathrm{v}$. Minister of Pensions and National Insurance, ${ }^{19}$ preferred Black's reasoning that where the draftsman incorporates a phrase ("reasonable doubt") which is known to have a recognised legal meaning, it should be assumed that Parliament intends it to be given that meaning; he therefore re-established the higher standard of proof for all cases under the

9. [1946] 1 K.B. 345 , at pp.350-51.

10. Ibid., at p. 351 .

11. [1946] 1 All E.R. 664, at p.665.

12. Parl. Debs. 1945-6 (5th series) H. of C., vol.421, cols.2077-82.

13. [1947] 2 All E. R. 372.

14. Per Edmund Davies $\mathrm{J}$ in 7 udd v. Minister of Pensions and N. I. [1965] 3 All E.R. 642, at p.649.

15. [1947] 2 All E.R. 372, at p.374.

16. [1945] S.C. 21.

17. Oliver v. Minister of Pensions 5 W.P.A.R. 153.

18. Minister of Pensions v. Greer [1958] N.I. 156.

19. [1965] 3 All E.R. 642. 
pension warrants. It is possible that Denning's apparent change of mind on this issue is explained by the context of Miller, which was one of the "unknown aetiology" cases which gave the tribunals their greatest difficulty. ${ }^{20}$

\section{Unanimity in decisions}

Denning's rule in Brain and Wilkes v. Ministry of Pensions, ${ }^{21}$ that a tribunal must be unanimous in rejecting the claimant's appeal, has also attracted unfavourable judicial comment. In Brain and Wilkes, as in three cases which had earlier been considered together by the Court of Session, the chairman dissented from the lay members who found against the claimant. The Court of Session clearly wished to discourage such an outcome without feeling able to go so far as to hold it wrongful: "without affirming that it is incompetent for a tribunal to decide by a majority, it appears to us that, when the question is the sufficiency of evidence to discharge such an onus, and when an express injunction has been laid upon the Tribunal to give the claimant the benefit of any reasonable doubt, only the most powerful considerations can justify the medical and service members in outvoting the legal chairman ...".22

Denning went further. With characteristic boldness and without drawing on precedent he sketched an elegant overview of the position. Starting from the proposition that "the rule whereby decisions are reached according to a majority vote is firmly established in all cases where one body alone is competent to reach a decision", he pointed out that because of the high risk of error ("it is almost as likely to be wrong as it is to be right"), ${ }^{23}$ the law has devised two methods of avoiding or reducing the risk. One is to give a right of appeal (as from magistrates to quarter sessions), the other is to require unanimity, or in default a re-hearing before a differently composed body. The latter, exemplified by jury trials, is the one appropriate to pension tribunals, where an appeal lies only on points of law. Because of the way judges direct juries, however, ("the commonsense way in which the rule as to unanimity is applied") ${ }^{24}$ re-trials are very rare.

The contrast between Denning's style of judgment in Brain, and that adopted by Lord Parker CJ in Picea Holdings v. London Rent Panel ${ }^{25}$ and by the Court of Appeal of New Zealand in Atkinson v. Bromn ${ }^{26}$ is instructive. Both took as their starting point the old case of Grundy v. Barker $(1798)^{27}$ in which Eyre CJ had found a well established rule that in public matters majority decisions were the rule, subject to contrary provision in the governing statute. Neither liked Denning's analogy with the jury which, indeed, seems hardly to fit comfortably a tribunal with specialist

20. [1947] 2 All E.R. 372.

21. [1947] 1 K.B. 625.

22. Brown v. Minister of Pensions [1946] S.C. 471, per Cooper LJ-C at p.476.

23. [1947] ] K.B. 625 , at p. 626 .

24. Ibid., at p.627.

25. [1971] 2 All E.R. 805.

26. [1963] N.Z.L.R. 755.

27. 1 Bos. \& P. 229. 
knowledge making findings of law and fact, and each distinguished Brain as "a very special case". ${ }^{28}$

The jury analogy, however, was taken up by Ormerod J in a way Denning can hardly have intended. In Minister of Pensions v. Horsey ${ }^{29}$ the Ministry successfully contended that a majority decision for the claimant must also be bad, for - as the judge pointed out - a jury's verdict must be unanimous whichever way they find. In Horsey, Ormerod J was unable to distinguish the two situations - either a body was entitled to proceed by a majority or it was not - and he felt bound to follow Denning in holding that these tribunals were not.

\section{Reviewing tribunal decisions}

\section{Interpreting the evidence}

Once the correct procedures for tribunals to adopt had been laid down by the courts and the meaning of certain key phrases in the governing statute and warrants, notably those defining "war risk injury" and "military service", had been elucidated, ${ }^{30}$ the question at issue in most appeals was whether the tribunal had correctly interpreted the medical evidence in the light of the burden of proof. ${ }^{31}$ The rigorous and painstaking scrutiny of the medical opinions on appeal to the judge became so microscopic that Ormerod $\mathrm{J}$ found it necessary to put in a caveat: "Neither the medical reports nor the reasons given by the Tribunals should be scrutinised in quite the way that pleadings might be scrutinised and dealt with as between lawyers on the hearing of a case, but at the same time, of course, I must be satisfied on a consideration of the whole of the documents that the questions which ought to be considered have been considered and considered from the proper point of view." ${ }^{32}$ Besides being intelligible to laymen, medical opinions should be full and detailed; ${ }^{33}$ they should not assert as a fact the very thing the tribunal was called upon to decide, that the disease was not caused or aggravated by military service, ${ }^{34}$ nor merely that it was endogamous, without fully explaining

28. [1963] N.Z.L.R. 755, at pp.767, 769; [1971] 2 All E.R. 805, at p.809. Commentators therefore view the pensions decisions as of doubtful authority: H.W.R. Wade, Administrative Law 5 th ed. (1982), p.812; S.A. de Smith, Fudicial Reviem of Administrative Action 3rd ed. (1973), p.350.

29. [1949] 2 K.B. 526.

30. Appeals involving these phrases continued to occur (see, e.g., Minister of Pensions v. Higham [1948] 2 K.B. 153) including several involving self-inflicted (negligent) injuries (Williams v. Minister of "Pensions 1 W.P.A.R. 755, Sharpe v. Minister of Pensions 1 W.P.A.R. 909, Weidman v. Minister of Pensions 3 W.P.A.R. 2215) and suicides (Fuller v. Minister of Pensions 3 W.P.A.R. 1617, Duff v. Minister of Pensions [1949] S.C. 63, McCrurie v. Minister of Pensions 2 W.P.A.R. 783, Blanchflomer v. Minister of Pensions 4 W.P.A.R. 887), but they form a very small proportion of reported appeals.

31. The appellant's statement of case had actually to be cast in the form of an assertion "that there was no evidence on which the Tribunal could reasonably come to its conclusion, or in other words that the conclusion drawn by the "Tribunal could not be reasonably drawn from the facts before them": Amstrong v. Minister of Pensions 3 W.P.A.R. 1449, at p.1467.

32. Rickman v. Minisler of Pensions 4 W.P.A.R. 873, at p.886. For examples see Minisler of Pensions v. Walters 1 W.P.A.R. 637 and Mepham v. Minister of Pensions 1 W.P.A.R. 515.

33. See, supra n.2.

34. Mansfield v. Minister of Pensions 1 W.P.A.R. 439. "Only too often a medical opinion has consisted merely of the assertion that the disease is not attributable or aggravated by war service without any reasons to support it": Armstrong v. Minister of Pensions 3 W.P.A.R. 1449 at pp.1467-68. 
how it arose and progressed. ${ }^{35}$ Only with this information could the tribunal do its job properly.

The most difficult cases were those in which a claimant fell victim during or after his military service to a disease whose aetiology was wholly unknown or imperfectly understood, whether a physical ailment such as cancer or a mental one such as schizophrenia. Under the old warrants, such a claimant had little hope of persuading the Ministry or a tribunal that he was entitled to a pension, but now the onus was on the Ministry to refute any causal connection and to the inherent difficulty of proving a negative was added those occasioned by the removal of the need for disability to be "directly" attributable or "materially" aggravated by service. $^{36}$

In early cases the Ministry deployed three sometimes overlapping arguments to meet this challenge, and met with some success before tribunals which were bemused by the unfamiliar reversal of the burden of proof and often reluctant to give full weight to the presumptions in favour of the claimant. ${ }^{37}$ The first argument was that where a disease of unknown aetiology occurred among civilians and servicemen alike, there could be nothing peculiar to service conditions affecting its onset or progress; the second was that, even where the disease had not manifested itself before enlistment, "according to the present accepted medical views of the disease in question, the claimant must have had a 'predisposition' or an 'inherent constitutional tendency' to that disease", 38 which was the primary cause; the third was to concede that the disease had been aggravated by military service, but to deny that it was attributable to it. ${ }^{39}$

In $B$ romn ${ }^{40}$ the Court of Session launched a strong attack on these arguments and on the Ministry's general approach. They disliked the resort to excessive jargon and technicality, for "the nature of the tribunal selected for the purposes of affirming or denying attributability, indicate in our view that the search is for causation no doubt, but not in the metaphysical or scientific sense but in the wider and more liberal sense in which 'the matter would be understood by the man in the street applying commonsense standards'." They were concerned lest "if the objectionable tendencies are not checked, it will soon be possible to prepare a

\section{McLean v. Minister of Pensions 1 W.P.A.R. 535.}

36. This was the government's concession to the "fit for service, fit for pension" lobby: Parl. Debs. 1942-3 (5th series) H. of C., vol.391, cols.716-22.

37. They were still being strongly criticised on this count by the Court of Sessions in several cases in 1947, notably in V. Scoll v. Minister of Pensions 1 W.P.A.R. 565; 7. Scolt v. Minister of Pensions 1 W.P.A.R. $589 ;$ L. Mitchell y. Minister of Pensions 1 W.P.A.R. 597.

38. Brown v. Minister of Pensions [1946] S.C. 471 , at p.476.

39. This was less favourable to the claimant since the degree of "aggravation" had then to be assessed and he might later find his pension stopped on the grounds that "the aggravation had passed away", i.e. that the increased severity of the disease or the acceleration in its progress brought about by service was now at an end. A number of these "passed away" cases began to come before the nominated judges in 1947.

40. [1946] S.C. 471. 
schedule of diseases for which pensions can never be awarded; and this we are convinced would be entirely contrary to the letter and the spirit of the Royal Warrants." 41

Denning certainly agreed that the arguments outlined above were logically flawed. In Nuttall v. Minister of Pensions ${ }^{42}$ he had already demolished the fallacy embodied in the argument from statistics, and in Stockwell v. Minister of Pensions ${ }^{43}$ he echoed the Scottish insistence that "a predisposition to a disease is not a disease". The fine distinction between attributability and aggravation was more difficult, and remained a pitfall for tribunals, but in Marshall v. Minister of Pensions ${ }^{44}$ he produced a beautifully lucid set of guidelines to distinguish between the two.

However, both English and Scottish judges eschewed the simplest approach, which was several times urged upon them in argument, ${ }^{45}$ that ex hypothesi, if the nature of a disease was not properly understood it could not be proved 'beyond reasonable doubt' that nothing in the claimant's military history had caused or aggravated it in his case. Edmund Davies $\mathrm{J}$, reviewing the case law which had developed, evidently felt strongly drawn to this argument ${ }^{46}$ and it is possible that Denning's preference for the lower, civil standard of proof in cases where the presumption in Article 4(3) did not apply owes something to his recognition of the excessive difficulties the higher burden would have imposed on the Ministry. ${ }^{47}$

Nevertheless Denning laid down stringent tests which the Ministry had to meet before it could discharge the burden of proof in these cases. First, there had to be enough knowledge of the disease to enable all the factors which might cause or aggravate it to be considered: while it remained wholly mysterious, it was impossible to do this and the claimant must succeed. ${ }^{48}$ Second, where exogenous factors might play a part, compelling medical evidence had to be adduced to refute the possible effect of any event or circumstance suggested either by the claimant, by medical opinions or in the Ministry's recital of his service history; it was not necessary however to deal with everything to which he might have been subjected

41. Ibid., at p. 476 .

42. [1946] 1 K.B. 345.

43. 1 W.P.A.R. 189. See also his rejection of the concept of a "latent disease" in Baird v. Minister of Pensions 1 W.P.A.R. 169 and of the search for a "predominant cause" in Hollom v. Minister of Pensions 1 W.P.A.R. 283.

44. 1 W.P.A.R. 785. The concession of aggravation sometimes backfired, e.g. in Dickerson v. Minister of Pensions I W.P.A.R. 561, but in Tuxford v. Minister of Pensions 3 W.P.A.R. 1549, Denning would not hold the concession against the Minister and remitted the case.

45. E.g., Saxby v. Minister of Pensions 1 W.P.A.R. 203; Docherty and Others v. Minister of Pensions 2 W.P.A.R. 655 .

46. Coe v. Minisler of Pensions and N. I. [1966] 3 All E.R. 172, at p.175.

47. See supra.

48. E.g., Donovan v. Minister of Pensions 1 W.P.A.R. 609 (Hodgkin's Disease); King v. Minister of Pensions 1 W.P.A.R. 809 (leukaemia); Docherty and Others v. Minister of Pensions 2 W.P.A.R. 655. 
regardless of some positive indication of relevance. ${ }^{49}$ Third, the evidence must be strong enough to meet whichever standard of proof the case demanded. ${ }^{50}$

\section{The role of the courts}

Denning's conception of the role of the nominated judge was quite remarkable in an era which a leading authority has described as forming "the great depression" in administrative law. It is highlighted by the contrasting approach of the Court of Session. The Scottish judges showed greater anxiety to avoid the pitfalls of "legalism" and to give effect to the "letter and the spirit of the royal warrants". They seem not to have been anxious to encourage appeals or to formulate detailed guidelines for the tribunals.

Denning was altogether more ambitious. He found, ironically, that the consequence of imposing upon the tribunals stricter judicial definitions of evidence, proof and procedure and insisting upon a minute scrutiny of the medical evidence, often tended to obscure the real merits of the case. Even where this produced a result favourable to the claimant, Denning felt that "it is unsatisfactory that a case of this kind should depend for its determination on the narrow construction of words in medical opinions. Cases should be determined on their real merits." ${ }^{51}$ Neither did it ensure consistency, for since the interpretation of evidence was still a matter for the tribunals ${ }^{52}$ differences in the quality and up-to-dateness of the evidence before them might lead to different findings in cases on similar facts concerning the same disease: "so far as the claimants are concerned, the cases are identical. It would give rise to an intolerable sense of grievance if the results varied according to the date at which the medical opinion was given or on the phraseology in which it was worded without regard to the real merits of the cases themselves. When the material facts are indistinguishable the consequences should be the same.",53

In order to achieve these goals of consistency, a more positive and creative supervision was needed and with the co-operation of Sir Harold Parker (the legal adviser to the Ministry, who regularly appeared before him) and the legal advisers to the British Legion it was duly implemented and described in some detail in Armstrong and Larkin v. Ministry of Pensions. ${ }^{54}$

49. Cf. Briggs v. Minister of Pensions 1 W.P.A.R. 211 (schizophrenia), Lightfoot v. Minister of Pensions 3 W.P.A.R. 1303 (cerebral haemorrhage) and Freeman v. Minister of Pensions 3 W.P.A.R. 1303 (cancer of colon), all successfully rebutted, with Crommie v. Minister of Pensions 1 W.P.A.R. 1152 (hypertension), Hurt v. Minister of Pensions 1 W.P.A.R. 525 (rheumatism), Bridge v. Minister of Pensions 1 W.P.A.R. 139(typhoid).

50. E.g., Parr v. Minister of Pensions 1 W.P.A.R. 511; Chapman v. Minister of Pensions 1 W.P.A.R. 917; Osgodby v. Minister of Pensions I W.P.A.R. 1011.

51. Walker v. Minister of Pensions 3 W.P.A.R. 1413, at p.1421.

52. A point he emphasised in Viner v. Minisler of Pensions 1 W.P.A.R. 997; Hardy v. Minister of Pensions 3 W.P.A.R. 1259.

53. Armstrong v. Minister of Pensions 3 W.P.A.R. 1449, at p.1467.

54. 3 W.P.A.R. 1449. 
Central to this new practice was the regular use of the power to remit cases for reconsideration, which was to be done whenever "the Superior Court can see that there was an error in law, but cannot say, one way or the other, whether the ultimate conclusion was wrong." 55 He listed nine circumstances in which it would be appropriate to remit, ${ }^{56}$ and in 1948 alone he followed this course in no fewer than five-sixths of reported appeals. In particular, it was used when the evidence before the tribunal did not justify the conclusion which it had reached, and was insufficient to establish the real merits of the claimant's case.

The process could also be used to promote consistency. As soon as a suitable "typical case" involving a common disease of unknown or doubtful aetiology arose, the Ministry and the Legion made sure that it was appealed; Denning would remit it for reconsideration with leave to adduce further medical evidence; the reconsidered decision, with the fullest and most authoritative medical opinions that could be procured, would then be brought back before the judge, who would be able to review the decision in the light of all the evidence $;{ }^{57}$ the case would then appear in the reports, together with a summary of the medical evidence, which would be available to tribunals considering other cases involving the same disease. ${ }^{58}$ Indeed, "the practice has been found so useful that when a disease of obscure origin first comes before the Court, the parties often agree for it to be remitted for reconsideration for the express purpose of obtaining an authoritative decision on it, see foyce's case." 59 In this way, before Armstrong, "signpost" decisions had already been reported for leukaemia, diabetes and some cancers, ${ }^{60}$ and the process became so commonplace that the editor of the reports simply noted of one case: "This case is reported as it is the "signpost" case of Hodgkin's Disease." $" 61$

55. Ibid., at p.1466. Denning derived this power from the "necessary implication of the Statute": s.6(2) provides that "where ... the Appellant or the Minister is dissatisfied with the decision of the Tribunal as being erroneous in point of law, he may ... appeal therefrom .... and the decision of [the] Judge shall be final and conclusive."

56. Where evidence has been wrongly admitted, or wrongly excluded; the tribunal misdirected itself in law, or where there is reasonable doubt that it has directed itself properly; where its procedure has been contrary to the rules or the requirements of practice; where there was reasonable ground for thinking that the decision might be wrong in law, but the facts were insufficiently stated to allow the Court to make a decision; where the parties agree to bring an "obscure origin" disease before the Court to secure an authoritative decision; where leave is granted out of time; other cases where the parties agree to it being remitted although there is no error in law. An earlier summary of his practice on appeals is in Alkinson v. Minister of Pensions 1 W.P.A.R. 981.

57. Armsirong v. Minister of Pensions 3 W.P.A.R. 1449, at pp.1467-68.

58. Such evidence was allowed in Slone v. Minister of Pensions 1 W.P.A.R. 1171 (decided in January, 1948, four months before Armstrong), and regularly thereafter.

59. Amstrong v. Minister of Pensions 3 W.P.A.R. 1449, at p.1468; 7oyce v. Minister of Pensions 1 W.P.A.R. 1235.

60. 3 W.P.A.R. 1449 , at pp. $1467-68$.

61. Wallis v. Minister of Pensions 4 W.P.A.R. 743. This practice was devised without reference either to the Lord Chancellor's Office or to the President of the Tribunals. After protests by the President (Sir Owen Beasley) it was slightly modified, but continued to achieve the desired result: PRO LCO 2/3730. The "signpost" practice was explained and approved by Ormerod J in 5 W.P.A.R. 47, at p.62. 
There were drawbacks to this course. One was that pending appeals to the tribunals were delayed, sometimes badly, while the result of a "signpost" case on their disease was awaited. ${ }^{62}$ Again, tribunals had to be warned not to follow the reported cases blindly where (as was usually the case) they held that a disease would not usually be attributable to or aggravated by war service, but carefully to consider any particular distinguishing facts in the instant case. ${ }^{63}$ There were also unfortunate cases in which the claimant succeeded in showing that on the evidence before the tribunal it had wrongly decided against him only for it to be ruled that evidence subsequently available in a "signpost" case was admissible which justified the refusal of a pension. ${ }^{64}$

Once again, the practice of the Court of Session makes an instructive contrast. They admitted the power to remit cases and occasionally exercised it, but when counsel for the Ministry of Pensions sought to persuade the court that there was a regular practice in England of remitting a case whenever the medical evidence was insufficient to justify the tribunal's conclusion, he was given a very rough ride. ${ }^{65}$ Lord Mackay criticised Denning's decision in one of the cases cited to him, and declined to accept that "the group of disconnected instances from $\mathrm{Mr}$ Justice Denning's court establishes any such habit or practice there", feeling that to remit cases in which the Ministry's evidence was insufficient to make out its case would be "apt to defeat the short purposes of the Act and Warrant". ${ }^{66}$ These criticisms were considered by Denning in Armstrong ${ }^{67}$ but he maintained, with doubtful plausibility, that the Scottish view that for remittance to be appropriate "some particular circumstances or failure or some peculiar needs of the general requirements of justice, would require to be shown" 68 was entirely consistent with his own. $\mathrm{He}$ admitted that there was some difference in approach but, with the support of both counsel, decided not to alter his practice to conform with Scotland. ${ }^{69}$

62. See, e.g., Bungey v. Minister of Pensions 3 W.P.A.R. 1523 ("widows' claims such as these should not be subjected to delay"), waiting on the signpost case of Ward v. Minister of Pensions 4 W.P.A.R. 521, not heard until July 1949, fourteen months later.

63. E.g., Rice v. Minister of Pensions 3 W.P.A.R. 1253; Garland v. Minister of Pensions 3 W.P.A.R. 1505. Cf. Ormerod J at 5 W.P.A.R. 62.

64. Clark v. Minister of Pensions 4 W.P.A.R. 283. Likewise, in a leukaemia case (Walson v. Minister of Pensions [1949] S.C. 107) on all fours with their own decision in Thorson v. Minister of Pensions 2 W.P.A.R. 655, where they had held that the Ministry had failed to discharge the burden of proof, the Court of Session ruled that evidence in the "signpost" case (Kinkaid v. Minister of Pensions [1948] W.N. 208) should be admitted at the re-hearing.

65. Bache v. Minister of Pensions [1948] S.C. 176.

66. Ibid., at p.191.

67. 3 W.P.A.R. 1449. The Court of Session had recently repeated its views in Docherty v. Minister of Pensions 2 W.P.A.R. 655.

68. [1948] S.C. 176, at pp.190-91.

69. 3 W.P.A.R. 1449 , at p.1470. 


\section{Conclusion}

How does Denning's work as the nominated judge fit in with recent verdicts on his judicial career? Professor Palley asserts that "it is a schoolman's game to analyse Denning's decisions by reference to logic and precedent, because he was so instrumental in his approach that, if convenient, he would ignore both"; ${ }^{70}$ he was "entirely result-orientated", "a naive utilitarian" who "abhorred technicality and believed in common sense", whose greatest contribution was the "re-emphasis of "justice"". "In a well-known quotation he has himself emphasised that "my root belief is that the proper role of the judge is to do justice to the parties before him." "I2 In administrative law he is said by Professor Jowell to have espoused an "activist model" of the judicial role which tends to the adoption of a "purposive" interpretation of statutes, ${ }^{73}$ claiming and asserting for the courts an "inherent jurisdiction to control all inferior tribunals, not in an appellate capacity, but in a supervisory capacity." descriptions, though they would draw different conclusions from them.

In pensions appeals, of course, he had no need to assert the inherent supervisory jurisdiction, because the appellate one was given - and limited - by the Act. His interpretation of that role, however, certainly conforms to the "activist" model and went well beyond the likely intentions of those responsible for the appeal provision. This is apparent in his characteristically broad interpretation of a "question of law", though that was shared by the Scottish courts. More distinctive was Denning's robust demolition of all obstacles placed in the path of would-be appellants to his court, whether by time limits, consents, administrative arrangements or bargains (and most remarkably his departure from the general principle that a later decision which casts doubt upon an earlier one affords no grounds for an appeal). ${ }^{76}$

Even more striking is the way he fashioned the appeals system into a regular means of imposing consistency of practice and interpretation on the tribunals. Successive Presidents, Ashby and Beasley, and some of the chairmen, found his encouragement of appeals and close supervision irksome. ${ }^{77}$ It is therefore ironical that the Franks Tribunal attributed the "high degree of consistency in their methods and decisions" to the appointment of a President. ${ }^{78}$

70. Lord Denning: The 7 udge and the Law, supra n.1, at p.344.

71. Ibid., at pp.253, 261, 364-65.

72. The Family Story (1981), at p.174.

73. Lord Denning: The Fudge and the Law, supra n.1, at pp.212-13.

74. Ibid, at p.213, quating Denning's decision in $R$. v. Northumberland Compensation Appeal Tribunal, Ex p. Shaw [1952] l K.B. 388.

75. E.g., P. Watchman and E. Young in Fustice, Lord Denning and the Constitution, supra n.1, pp.157 et seq..

76. Supra, pp.98-102

77. See, e.g., PRO LCO 2/3730: Beasley to R. Rieu, 28 February 1949.

78. Cmnd. 218 of 1957 , para. 220. 
The object of his interventionism was to ensure that all claimants got "a fair crack of the whip" and that the tribunals adhered to the Warrant, the Act, the Rules and "the requirements of justice". ${ }^{79}$ What justice seems to have required was that their procedures and conduct should approximate as closely as the terms of the governing regulations allowed and their own special composition and functions permitted to the traditional model of an English court. However, because they were not a court, they had to be unanimous in their decisions and in the absence of counsel had to take particular care to assist the claimant in presenting his case and understanding his rights. ${ }^{80}$

In pursuit of his insistence on due process, Denning was quite indifferent to any inconvenience which it imposed on tribunals or administrators. If the Minister made a mistake in preparing cases "he has made much trouble for himself", 81 and he must live with the consequences of thousands of wrongly decided appeals; if majority decisions were impermissible it mattered not that the Ministry would have to search back through two and a half years of appeals to find out instances; when Denning insisted that appeals should lie (indirectly) even from the Special Review Tribunals, he was unimpressed by the argument that he thereby defeated their entire purpose. Due process was inconvenient: it made heavy demands of the tribunal chairmen as well as the Ministry's officials, and it led to a profusion of delays, adjournments and references. When Denning encouraged tribunals to resort as a regular practice to independent medical specialists, when he accepted appeals in their thousands rather than as "exceptional cases", or remitted numerous cases for reconsideration, he knew that it would cost the Treasury more than it had budgeted for, but felt that a worthwhile price to pay for justice. ${ }^{82}$ Moreover, in ensuring that justice was done he would have no truck with technicalities: in one case he pronounced "We will do it anyway: I do not want to go too much on technicalities." 83

It is important, however, to stress the limits of Denning's "justice" in pensions cases. It was essentially procedural, not substantive. In marked contrast with the cases on deserted or divorced wives, with which he was shortly to create such a stir, he felt no need to strain statutes or make new law in order to create or amplify rights. Of course disability pensions were a statutory creation of recent origin, but even so there might well have been a temptation to lean consistently towards the claimant in interpreting the legislation, for there was a widespread popular feeling (at least during and immediately after the war) that the provision was mean and inadequate. Moreover there was no effective curb on the nominated judge's decisions and pensions were not a party political issue. Yet despite Professor

79. Armstrong v. Minister of Pensions 3 W.P.A.R. 1449, at p.1466.

80. Supra, pp.108-111, 114-116.

81. Starr, Nuttall and Boume v. Minister of Pensions [1946] 1 K.B. 345, at p.353.

82. PRO LCO $2 / 3709$. The Treasury complained of the growing resort to specialists as early as May 1947: B. J. Grey to Sir A. Napier, 13 May 1947.

83. Shore v. Minister of Pensions 3 W.P.A.R. 1867. 
Palley's judgment on Starr, ${ }^{84}$ the general tenor of Denning's judgments on the substantive question of entitlement was not very liberal. It is true that in Ministry of Pensions v. Chennell ${ }^{85}$ he took a broad view of causation in defining "a war risk injury", but his rulings on that and cognate issues closely followed the settled case law on workmen's compensation and in one case his interpretation was narrower than the Court of Session. ${ }^{86}$ Later, on the important question of attributability/ aggravation he declined to accept the argument that ex hypothesi the Ministry could not disprove it in diseases of unknown aetiology whereas Edmund Davies J might have done so; he imposed on the Ministry a lower standard of proof in cases outside article 4(3) than that same judge did, ${ }^{87}$ and although he was vigilant to detect fallacies in tribunals' reasoning and deficiencies in evidence, he generally remitted such cases rather than reversing the decision, ${ }^{88}$ while even his insistence on unanimity turned out to be a two-edged sword.

Denning showed himself aware that too great an eagerness to pounce on minor flaws might be counter-productive: "I have noticed that sometimes the Minister concedes aggravation in a borderline case on compassionate grounds, when he might have refused it; and the Tribunal sometimes makes an award by stretching a point in the man's favour when if the matter were pressed to its logical conclusion they might be forced to say it was neither attributable to nor aggravated by war service. So, if the dilemma were forced too far, it might work out disadvantageously to the men." 89

The men, evidently, were to have what the statute and Warrant entitled them to, but no more. It seems likely that left to their own devices, some tribunals would have given them rather less. Ashby's views on key questions were narrower than the Ministry's own, ${ }^{90}$ and it is unlikely that many tribunals would have applied themselves rigorously to determine whether the burden and standard of proof demanded of the Ministry was satisfied by the evidence; rather they would have

84. [1946] K.B. 345 ; supra p.96, n.7.

85. [1946] K.B. 250.

86. Staynings v. Minister of Pensions. In Minister of Pensions v. Higham [1948] 2 K.B. 153 he agreed to prefer the Scottish decision in Ballantyne v. Minister of Pensions [1947] 1 All E.R. 347. This was one of several embarrassing divergencies between the two countries. A few weeks earlier, Denning had made general observations on the treatment of Scottish decisions in pensions cases, since he had been told that 'forum-shopping' had been occurring as a result of the differences: "I lay down for myself, therefore, the rule that, where the Court of Session have felt compelled to depart from a previous decision of this court, that it is a strong reason for my reconsidering the matter; and if on reconsideration I am left in doubt of the correctness of my own decision, then I shall be prepared to follow the decision of the Court of Session, at any rate in those cases when it is in favour of the man, because he should be given the benefit of the doubt." Nevertheless Higham is the only case in which Denning did change his own view to conform to a Scottish decision and in Annstrong he declined to do so.

87. Supra, pp.108-111, 114-116.

88. Most of the remitted cases eventually went against the claimant.

89. Matthews v. Minister of Pensions 3 W.P.A.R. 1993.

90. PRO LCO 2/3702: correspondence re "war risk injury" and his decision in Saffell's appeal; 2/3718: Coldstream to Rieu, 27 November 1946 (out of time appeals). 
weighed the medical opinions in a commonsense sort of way in the light of the medical member's advice. But Denning's idea of equal justice for all inevitably deprived some of a pension, and the reports make clear his anxiety that although the claimant must have the benefit of any reasonable doubt, such doubts should be eliminated by further evidence where possible rather than actively sought out in order to assist him.

It is instructive also to follow the impact of Denning's decisions on the departments responsible for the pension legislation and the tribunals. The Ministry of Pensions certainly grew dismayed by his generosity in admitting appeals out of time and were sometimes critical of his approach, ${ }^{91}$ while even the Lord Chancellor's Office, which followed its invariable practice of defending judges against criticism from other departments, evidently found fames and Revely unpalatable. ${ }^{92}$ Nevertheless, once it had become clear that he was not seeking openings to admit claimants to pensions through technical imperfections in the decision-making and appeal process, they were readily reconciled to him. The development of the "signpost case" strategy in particular shows that there was more co-operation than confrontation between the judge and the Ministry, certainly more than a cursory reading of the cases reported in the general reports might suggest. However, although experience may have modified the view that a form of appeal which allowed a single judge to make law which was effectively unappealable was a mistake, it may be significant that the model was not adopted for other new tribunals set up around this time. ${ }^{93}$

Denning's achievement in pensions cases, therefore, was principally to impose on an informal, expert tribunal, the traditional model of due process developed by the courts of law, and to ensure by unprecedently close supervision that the claimants received the "justice" to which they were entitled. What he did not do was stretch and bend the law so as to favour the claimants in their fight for pensions. There is an impressive coherence and consistency in his pensions decisions which shines out in the poverty of English administrative law in the 1940s and deserves recognition.

91. PRO LCO $2 / 3714$.

92. [1947] 1 K.B. 767; 3 W.P.A.R. 1573. PRO LCO 2/3714: Rieu's file notes 3 July 1947; 23 July 1948.

93. PRO LCO 2/3714: G. P. Coldstream to Sir A. Napier, 9 September 1947. Cf. the Lands Tribunal Act 1949; Gas Arbitration Act 1948; Iron and Steel Act 1949; Medical Act 1950; Courts-Martial Appeals Act 1951. 